\title{
The Emergence of Cross-Border Insurance Groups within Europe with Centralised Risk Management
}

\author{
Dirk Schoenmaker ${ }^{\mathrm{a}}$, Sander Oosterloo ${ }^{\mathrm{b}}$ and Otto Winkels ${ }^{\mathrm{c}}$ \\ ${ }^{\mathrm{a}}$ Department of Economics and Business, VU University Amsterdam, De Boelelaan 1105, Amsterdam 1081 \\ HV, The Netherlands. \\ E-mail: dschoenmaker@feweb.vu.nl \\ ${ }^{\mathrm{b}}$ Financial Markets Policy Department, Ministry of Finance, The Hague, Netherlands. \\ E-mail: sanderoosterloo@hotmail.com \\ ${ }^{\mathrm{c}}$ Aegon, Operational Risk Management, The Hague, Netherlands. \\ E-mail: OWinkels@AEGON.NL
}

This paper analyses the degree of internationalisation of insurance business. Using a novel data set of 25 large EU insurance groups, we find that the insurance industry has a strong international orientation. About 55 percent of the business of these large insurance groups is conducted abroad. The cross-border activities are predominantly within Europe (30-35 percent) and less so in the rest of the world (20-25 percent). Next, this paper examines the impact of internationalisation on the organisational structure. We find a clear trend towards centralising risk and capital management activities within large insurance groups, though insurance remains at the same time a local business. Applying the hub and spoke model, we identify which functions are executed at the centre (hub) and which functions are performed at the level of the local business units (spokes).

The Geneva Papers (2008) 33, 530-546. doi:10.1057/gpp.2008.15

Keywords: insurance companies; international business; organisational structure

Jel classification: F23; G22; L22

\section{Introduction}

The globalisation of financial institutions has accelerated over the last two decades. While there is a widespread literature on the globalisation of banks, ${ }^{1}$ hardly any studies have examined the degree of internationalisation of insurance companies. The aim of this paper is to fill this gap by exploring the current state of cross-border activities of individual insurance companies.

The empirical analysis in this paper is based on a new data set, comprising a crosssection of the 25 largest EU insurance groups. In the literature, internationalisation is often measured by examining in how many countries financial groups provide one or more of their services. ${ }^{2}$ In this paper, we take a different approach based on earlier work. ${ }^{3}$ The level of cross-border penetration of insurance groups is measured using the

\footnotetext{
${ }^{1}$ E.g. Moshirian (2006); Berger and DeYoung (2006).

${ }^{2}$ E.g. Berger et al. (2003).

${ }^{3}$ Schoenmaker and Oosterloo (2005).
} 
Transnationality Index (TNI) developed by Sullivan. ${ }^{4}$ The TNI is an unweighted average of three indicators (assets, revenues and employees) and measures foreign activity of an insurance group as a percentage of total activity of that insurance group. The TNI provides a relatively full and stable measure of cross-border activity.

Next, we examine how internationalisation affects the organisational structure of insurance groups. The international presence may induce a growing demand for coherent policies and a central steering mechanism within the organisation. With respect to risk management, one of the major developments has been the shift to a more holistic approach. Such "enterprise risk management" has also led to the wider adoption of chief risk officers (CROs). However, the insurance business still has a strong local focus, as most countries differ with respect to applicable rules and regulations, social security systems, language, culture, etc. To gain insight into the organisational changes, in-depth interviews with top managers of a number of large European insurance groups were conducted.

The remainder of the paper is organised as follows. The next section examines the current state of cross-border activities within the EU insurance market. After examining the existing literature, we present the data on individual insurance groups. The subsequent section presents the findings of the in-depth interviews on the organisational structure of large EU insurance groups. In the final section, we discuss the implications of our empirical findings and draw conclusions.

\section{Measuring cross-border activities of the European insurance industry}

\section{Internationalisation}

Generally, it is found that insurance groups are relatively internationally oriented. Van der Zwet ${ }^{5}$ examines the geographic distribution of revenues of the 38 largest financial groups worldwide in 2000. She finds that insurance groups are significantly more internationally oriented than banks. Whereas banks have a clear home bias (earning on average 61 percent of their revenues in their home country), insurance companies have a foreign bias (earning 65 percent of their revenues in host countries). Moreover, it appears that European financial groups are more strongly internationally oriented than their American and Asian peers. Van der Zwet argues that this may be due to the internal market for financial services; when Europe is treated as one country, EU financial groups are as much focussed on foreign markets as financial groups located in Japan, Hong Kong, Australia and the U.S.A. Other studies, such as those by the $\mathrm{OECD}^{6}$ and $\mathrm{CEA}^{7}$ confirm that the European insurance industry is strongly internationally diversified.

While aggregate data on cross-border penetration of insurance companies are generally available, no attempt has been made to analyse the cross-border activities of

\footnotetext{
${ }^{4}$ Sullivan (1994).

${ }^{5}$ Van der Zwet (2003).

${ }^{6}$ OECD (2005).

${ }^{7}$ CEA (2005).
} 
individual insurance groups. However, aggregate data might hide significant differences between the international activities of individual insurance firms. The aim of the empirical investigation of cross-border business of insurance firms is twofold. First, what is the trend in the insurance industry? More particularly, has cross-border business increased since the establishment of Economic and Monetary Union (EMU) in 1999? Second, what is the current share of cross-border business of individual insurance firms? How many "European" insurance groups have emerged? In order to answer the first question, we examine aggregate data on the cross-border penetration of insurance groups in Europe. The second question is answered by examining the foreign activities of a cross-section of individual insurance groups.

The literature on the internationalisation of financial services is extensive, but mostly focuses on banks. ${ }^{8}$ A first line of research examines the patterns of foreign direct investment (FDI). How large are the flows into financial institutions in (emerging) economies and what is the impact on the financial system of these economies? A second line of research looks at the cross-border expansion of individual financial institutions. Internationalisation can be measured by examining a specific aspect of the international activities of a financial group. A separate approach is to look at the full set of activities of financial institutions. In the literature on multinational firms, Sullivan ${ }^{9}$ reviews 17 studies estimating the degree of internalisation based on a single item indicator. Using just a single indicator increases the possibility for errors, as the indicator could, for example, be more susceptible to external shocks. Sullivan develops the TNI, which is based on three indicators (see below). The TNI provides a full and stable measure of internationalisation. Slager ${ }^{10}$ and Schoenmaker and Oosterloo ${ }^{11}$ have applied this Index to banking. Extending earlier work, we follow this approach and apply it to insurance groups.

\section{Transnationality index}

We have collected a data set on cross-border penetration of 25 large EU insurance firms, based on the Transnationality Index. ${ }^{12}$ This index is calculated as an unweighted average of (i) foreign assets to total assets, (ii) foreign income to total income and (iii) foreign employment to total employment.

The indicators are constructed as follows:

- Assets: This indicator is composed of goodwill, the investments of the group companies, asset backing contracts with the financial risk borne by policyholders (unit-linked), investments from non-insurance activities, investments in affiliated companies, reinsurers' share of insurance liabilities, receivables, cash and cash equivalents, prepayments and accrued income, and the remaining other assets. ${ }^{13}$

\footnotetext{
${ }^{8}$ See Moshirian (2006) for an overview.

${ }^{9}$ Sullivan (1994).

${ }^{10}$ Slager (2004).

${ }^{11}$ Schoenmaker and Oosterloo (2005).

12 Sullivan (1994).

${ }^{13}$ In situations where it is impossible to separate the specific assets of the insurance activities of large financial conglomerates, bank assets have also been included.
} 
- Revenue: This indicator is based on the total gross or net written premiums in a year, depending on which standard is used in the geographical analysis of the report.

- Employees: This indicator measures the average or year end's number of employees, depending on the data availability.

We use all the information we have available for individual insurance groups. For some insurance groups we have information on all three indicators, for others we have information on two indicators and for a couple we only have information on one of the indicators. If data on one (or two) indicator(s) are available, only this indicator is used.

It is interesting to distinguish between regional expansion (e.g. within the European Union) and global expansion of insurance groups. The data on the TNI are therefore broken down into activities in the home market $(h)$, the rest of Europe $(e)$ and the rest of the world $(w)$.

\section{Classifying insurance firms}

Following the geographical breakdown of activities, insurance companies are classified as domestic, regional or global firms in this paper. Domestic firms are defined as follows:

(1) More than 50 percent of their business is conducted in the home market $(h>0.5)$.

This first criterion makes a distinction between domestic and international insurance firms. Firms that conduct the majority of their business in their home country are regarded as domestic firms. International firms are divided into regional and global insurance firms. Regional firms are defined as:

(1) 50 percent or more of their business is conducted abroad $(h \leqslant 0.5)$.

(2) 25 percent or more of their business is conducted within the region $(r \geqslant 0.25)$.

The second criterion identifies regional insurance firms among the international ones. International firms that have a sizeable part of their business in the rest of the region (e.g. Europe) are regarded as regional insurance firms ("European firms"). The total business of an insurance group in the region is a sum of the home activities and the activities in the rest of the region $(h+r)$.

Global insurance firms are then defined as:

(1) 50 percent or more of their business is conducted abroad $(h \leqslant 0.5)$.

(2) Less than 25 percent of their business is conducted within the region $(r<0.25)$.

The remaining group of insurance firms is of a global nature. These firms have no gravity of business at home or in the rest of the region. They operate on a truly global scale. Our classification only distinguishes between domestic, regional and global insurance firms. A further distinction could be made by counting the number of countries in which international firms are operating. ${ }^{14}$ As the focus of this paper is on domestic versus international insurance activities, we do not include this further breakdown.

\footnotetext{
${ }^{14}$ Sullivan (1994)
} 


\section{Data on cross-border activities}

To analyse the geographic segmentation of EU insurance groups, we examine the consolidated income statements and balance sheets of the 25 largest EU insurance groups. The top 25 of EU insurance groups are selected on the basis of gross written premium in 2006. The data are taken from the annual reports of these insurance groups.

Table 1 presents the outcome of the analysis of the cross-border penetration of 25 large EU insurance groups. To interpret the data in Table 1, we first make a distinction between domestic and international insurance groups. As defined in the previous section, an insurance firm is "international" when 50 percent or more of its business is conducted abroad $(h \leqslant 0.5)$. In Table 1 , the insurance groups that are considered to be "international" have been shaded grey. It is shown that over the sample period about half of the insurance groups can be labelled as being "international". This finding corresponds with earlier research, ${ }^{15}$ which suggests that EU insurance groups have a strong international focus. Table 1 shows further that there is a specific focus on the European continent within the international activities.

Table 2 divides the "international" insurance groups into two categories: (i) European insurance groups $(e \geqslant 0.25)$ and (ii) global insurance groups $(e<0.25)$. This table shows that in 2000 eight insurance groups can be regarded as "European". In the following years this number shows a slight increase. In 2003 the number of insurance groups that can be regarded as "European" rises to nine and in 2005 to 10. The number of European insurance groups drops back to eight in 2006. The number of "global" insurance groups is fairly constant; it varied between three and four over the sample period. The overall conclusion is that most of these "international" insurance groups can thus be regarded as "European". Over the whole sample period about three quarters of the "international" groups can be labelled as a "European" insurance group.

\section{Sensitivity analysis}

Although the criteria for classifying insurance groups are intuitive, they are somewhat arbitrary as well. We therefore conducted a sensitivity analysis. To see whether more insurance groups have "significant" cross-border business in the European context, the criteria are lowered by 10 percent and by 20 percent, respectively. An insurance group is then classified as an "international" insurance group if it conducts more than 45 percent, respectively 40 percent of its business abroad $(h \leqslant 0.55 ; h \leqslant 0.60)$. In this case an insurance group is regarded as "European" as it conducts more than 22.5 percent, respectively 20 percent, of its business in the rest of Europe $(e \geqslant 0.225$; $e \geqslant 0.20)$.

Table 3 shows the result of this sensitivity analysis. It reproduces the number of groups that would be regarded as European under the relaxation of the criteria and identifies the insurance groups that would have been added. We find that only one to three European insurance groups are added under the 10 and 20 percent relaxation of

\footnotetext{
${ }^{15}$ See Van der Zwet (2003).
} 
Table 1 Categories of international insurance groups within the 25 large EU insurance groups

\begin{tabular}{|c|c|c|c|c|c|c|c|c|c|c|c|c|c|c|c|c|c|c|c|c|c|c|c|c|}
\hline & \multicolumn{2}{|l|}{ Insurance Groups } & \multirow{2}{*}{$\begin{array}{l}\text { GWP } 2006 \\
\text { in EUR mln }\end{array}$} & \multicolumn{3}{|c|}{2000} & \multicolumn{3}{|c|}{2001} & \multicolumn{3}{|c|}{2002} & \multicolumn{3}{|c|}{2003} & \multicolumn{3}{|c|}{2004} & \multicolumn{3}{|c|}{2005} & \multicolumn{3}{|c|}{2006} \\
\hline & & & & $h$ & $e$ & $w$ & $h$ & $e$ & $w$ & $h$ & $e$ & $w$ & $h$ & $e$ & $w$ & $h$ & $e$ & $w$ & $h$ & $e$ & $w$ & $h$ & $e$ & $w$ \\
\hline 1. & Allianz & $\mathrm{DE}$ & 91,095 & 35 & 44 & 21 & 41 & 40 & 19 & 39 & 41 & 20 & 39 & 40 & 21 & 39 & 41 & 20 & 36 & 45 & 19 & 35 & 46 & 20 \\
\hline 2. & Axa & FR & 72,099 & 26 & 41 & 34 & 25 & 42 & 34 & 26 & 44 & 31 & 26 & 44 & 31 & 26 & 45 & 29 & 27 & 44 & 29 & 26 & 44 & 30 \\
\hline 3. & Generali & IT & 63,152 & 34 & 60 & 7 & 34 & 60 & 8 & 36 & 60 & 6 & 39 & 57 & 4 & 39 & 58 & 4 & 40 & 54 & 6 & 38 & 58 & 5 \\
\hline 4. & Aviva & UK & 50,033 & 47 & 31 & 22 & 50 & 33 & 17 & 52 & 35 & 13 & 53 & 37 & 10 & 51 & 38 & 10 & 49 & 42 & 10 & 51 & 38 & 11 \\
\hline 5. & ING & NL & 46,835 & 29 & 21 & 51 & 22 & 20 & 58 & 22 & 20 & 58 & 24 & 21 & 56 & 26 & 15 & 59 & 24 & 15 & 61 & 23 & 15 & 62 \\
\hline 6. & Zurich Financial Services & $\mathrm{CH}$ & 37,018 & 13 & 46 & 42 & 12 & 42 & 46 & 10 & 52 & 39 & 10 & 57 & 33 & 9 & 60 & 32 & 11 & 53 & 36 & 11 & 54 & 35 \\
\hline 7. & CNP & FR & 31,947 & 99 & 1 & 0 & 97 & 1 & 2 & 86 & 5 & 11 & 84 & 5 & 11 & 89 & 3 & 8 & 83 & 9 & 8 & 83 & 9 & 8 \\
\hline 8. & Credit Agricole & FR & 26,100 & 90 & 5 & 5 & 90 & 5 & 5 & 90 & 5 & 5 & 90 & 5 & 5 & 90 & 5 & 5 & 90 & 5 & 5 & 90 & 5 & 5 \\
\hline 9. & $\mathrm{AEGON}^{\mathrm{a}}$ & NL & 24,570 & 16 & 27 & 56 & 16 & 26 & 58 & 16 & 27 & 57 & 21 & 26 & 54 & 20 & 26 & 54 & 19 & 26 & 55 & 18 & 31 & 51 \\
\hline 10. & Prudential $^{\mathrm{b}}$ & UK & 24,012 & 53 & 1 & 45 & 49 & 1 & 49 & 45 & 1 & 53 & 44 & 2 & 54 & 44 & 2 & 54 & 40 & 1 & 59 & 36 & 0 & 64 \\
\hline 11. & Talanx & $\mathrm{DE}$ & 19,368 & 31 & 28 & 41 & 31 & 28 & 41 & 31 & 28 & 41 & 46 & 25 & 29 & 47 & 28 & 26 & 45 & 29 & 27 & 53 & 26 & 21 \\
\hline 12. & Skandia/Old Mutual ${ }^{\mathrm{c}}$ & UK & 21,312 & 27 & 33 & 41 & 29 & 37 & 34 & 43 & 46 & 12 & 42 & 50 & 8 & 37 & 53 & 10 & 36 & 53 & 12 & 20 & 28 & 52 \\
\hline 13. & HBOS & UK & 17,777 & 90 & 5 & 5 & 90 & 5 & 5 & 90 & 5 & 5 & 90 & 5 & 5 & 90 & 5 & 5 & 90 & 5 & 5 & 90 & 5 & 5 \\
\hline 14. & Ergo & $\mathrm{DE}$ & 15,930 & 87 & 13 & 0 & 85 & 15 & 1 & 85 & 15 & 1 & 85 & 15 & 1 & 85 & 15 & 0 & 85 & 15 & 0 & 84 & 16 & 0 \\
\hline 15. & BNP Paribas & FR & 15,600 & 58 & 23 & 20 & 58 & 23 & 20 & 58 & 23 & 20 & 53 & 28 & 20 & 57 & 23 & 20 & 55 & 25 & 21 & 51 & 30 & 19 \\
\hline 16. & Eureko & NL & 14,302 & 63 & 37 & 0 & 58 & 42 & 0 & 61 & 39 & 0 & 79 & 21 & 0 & 78 & 22 & 0 & 87 & 13 & 0 & 89 & 11 & 0 \\
\hline 17. & Fortis & $\mathrm{BE}$ & 13,984 & 34 & 30 & 35 & 30 & 36 & 33 & 32 & 35 & 33 & 34 & 34 & 32 & 45 & 46 & 8 & 44 & 48 & 8 & 43 & 49 & 8 \\
\hline 18. & Groupama & FR & 13,884 & 87 & 12 & 1 & 87 & 12 & 1 & 87 & 13 & 1 & 85 & 15 & 1 & 86 & 13 & 1 & 86 & 13 & 1 & 83 & 16 & 1 \\
\hline 19. & Swiss Life & $\mathrm{CH}$ & 13,733 & 52 & 49 & 0 & 55 & 45 & 0 & 51 & 49 & 0 & 46 & 54 & 0 & 47 & 53 & 0 & 46 & 54 & 0 & 44 & 56 & 0 \\
\hline 20. & Fondiaria-Sai & IT & 9,987 & 100 & 0 & 0 & 100 & 0 & 0 & 100 & 0 & 0 & 100 & 0 & 0 & 99 & 1 & 0 & 99 & 1 & 0 & 99 & 1 & 0 \\
\hline \multirow[t]{2}{*}{21.} & Royal \& & UK & 9,328 & 46 & 21 & 34 & 45 & 20 & 35 & 43 & 21 & 37 & 45 & 27 & 29 & 47 & 33 & 20 & 46 & 33 & 21 & 46 & 35 & 19 \\
\hline & Sun Alliance & & & & & & & & & & & & & & & & & & & & & & & \\
\hline 22. & RBS Group & UK & 9,297 & 86 & 4 & 11 & 83 & 4 & 5 & 82 & 5 & 13 & 82 & 5 & 13 & 79 & 5 & 16 & 78 & 6 & 16 & 79 & 6 & 15 \\
\hline 23. & Unipol & IT & 8,717 & 95 & 3 & 2 & 95 & 3 & 2 & 95 & 3 & 2 & 95 & 3 & 2 & 95 & 3 & 2 & 95 & 3 & 2 & 95 & 3 & 2 \\
\hline 24. & Lloyds TSB & UK & 7.027 & 90 & 5 & 5 & 90 & 5 & 5 & 90 & 5 & 5 & 90 & 5 & 5 & 90 & 5 & 5 & 90 & 5 & 5 & 90 & 5 & 5 \\
\hline \multirow[t]{5}{*}{25.} & Legal \& General ${ }^{\mathrm{b}}$ & UK & 6,383 & 91 & 5 & 5 & 91 & 4 & 5 & 91 & 5 & 5 & 91 & 5 & 5 & 91 & 5 & 5 & 86 & 8 & 6 & 86 & 8 & 6 \\
\hline & Weighted average & & & 46 & 31 & 24 & 45 & 30 & 25 & 45 & 31 & 24 & 47 & 32 & 22 & 48 & 32 & 20 & 46 & 32 & 21 & 46 & 32 & 22 \\
\hline & Number of domestic insur & groups & & & 14 & & & 13 & & & 14 & & & 13 & & & 13 & & & 12 & & & 14 & \\
\hline & Number of European insu & groups & & & 8 & & & 8 & & & 7 & & & 9 & & & 9 & & & 10 & & & 8 & \\
\hline & Number of global insuran & oups & & & 3 & & & 4 & & & 4 & & & 3 & & & 3 & & & 3 & & & 3 & \\
\hline
\end{tabular}


Table 2 Categories of international insurance groups within the 25 large EU insurance groups

\begin{tabular}{|c|c|c|c|c|c|c|c|}
\hline Category & 2000 & 2001 & 2002 & 2003 & 2004 & 2005 & 2006 \\
\hline \multirow[t]{10}{*}{ European } & 1. Allianz & 1. Allianz & 1. Allianz & 1. Allianz & 1. Allianz & 1. Allianz & 1. Allianz \\
\hline & 2. AXA & 2. AXA & 2. AXA & 2. AXA & 2. AXA & 2. AXA & 2. AXA \\
\hline & 3. Generali & 3. Generali & 3. Generali & 3. Generali & 3. Generali & 3. Generali & 3. Generali \\
\hline & 4. Aviva & 4. Aviva & 6. Zurich Financial & 6. Zurich Financial & 6. Zurich Financial & 4. Aviva & 6. Zurich Financial \\
\hline & 6. Zurich Financial & 6. Zurich Financial & Services & Services & Services & 6. Zurich Financial & Services \\
\hline & Services & Services & 11. Talanx & 11. Talanx & 11. Talanx & Services & $\begin{array}{l}\text { 12. Skandia/Old } \\
\text { Mutual }\end{array}$ \\
\hline & $\begin{array}{l}\text { 12. Skandia/Old } \\
\text { Mutual }\end{array}$ & $\begin{array}{l}\text { 12. Skandia/Old } \\
\text { Mutual }\end{array}$ & 17. Fortis & 17. Fortis & 17. Fortis & $\begin{array}{l}\text { 12. Skandia/Old } \\
\text { Mutual }\end{array}$ & 19. Swiss Life \\
\hline & 17. Fortis & 17. Fortis & & 19. Swiss Life & 19. Swiss Life & 17. Fortis & $\begin{array}{l}\text { 21. Royal \& Sun } \\
\text { Alliance }\end{array}$ \\
\hline & & & & $\begin{array}{l}\text { 21. Royal \& Sun } \\
\text { Alliance }\end{array}$ & $\begin{array}{l}\text { 21. Royal \& Sun } \\
\text { Alliance }\end{array}$ & 19. Swiss Life & \\
\hline & & & & & & $\begin{array}{l}\text { 21. Royal \& Sun } \\
\text { Alliance }\end{array}$ & \\
\hline \multirow[t]{4}{*}{ Global } & 5. ING & 5. ING & 5. ING & 5. ING & 5. ING & 5. ING & 5. ING \\
\hline & 9. AEGON & 9. AEGON & 9. AEGON & 9. AEGON & 9. AEGON & 9. AEGON & 9. AEGON \\
\hline & 21. Royal \& Sun & 10. Prudential & 10. Prudential & 10. Prudential & 10. Prudential & 10. Prudential & 10. Prudential \\
\hline & & $\begin{array}{l}\text { 21. Royal \& Sun } \\
\text { Alliance }\end{array}$ & $\begin{array}{l}\text { 21. Royal \& Sun } \\
\text { Alliance }\end{array}$ & & & & \\
\hline
\end{tabular}

Source: Table 1. 
Table 3 Sensitivity analysis of number of European insurance groups

\begin{tabular}{|c|c|c|c|c|c|c|c|c|}
\hline & $\begin{array}{l}\text { Relaxation of } \\
\text { criteria }\end{array}$ & 2000 & 2001 & 2002 & 2003 & 2004 & 2005 & 2006 \\
\hline $\begin{array}{l}\text { Number of European } \\
\text { insurance groups }\end{array}$ & $10 \%$ & 9 & 9 & 9 & 11 & 10 & 11 & 11 \\
\hline \multirow{2}{*}{$\begin{array}{l}\text { Insurance groups } \\
\text { added to the set of } \\
\text { European insurance } \\
\text { groups }\end{array}$} & $10 \%$ & 19. Swiss Life & 19. Swiss Life & $\begin{array}{l}\text { 4. Aviva } \\
\text { 19. Swiss Life }\end{array}$ & $\begin{array}{l}\text { 4. Aviva } \\
\text { 18. BNP Paribas }\end{array}$ & 4. Aviva & 15. BNP Paribas & $\begin{array}{l}\text { 4. Aviva } \\
\text { 11. Talanx } \\
\text { 15. BNP Paribas }\end{array}$ \\
\hline & $20 \%$ & 15. BNP Paribas & $\begin{array}{l}\text { 15. BNP Paribas } \\
\text { 16. Eureko }\end{array}$ & 15. BNP Paribas & - & 15. BNP Paribas & - & - \\
\hline
\end{tabular}

Source: Table 1. 


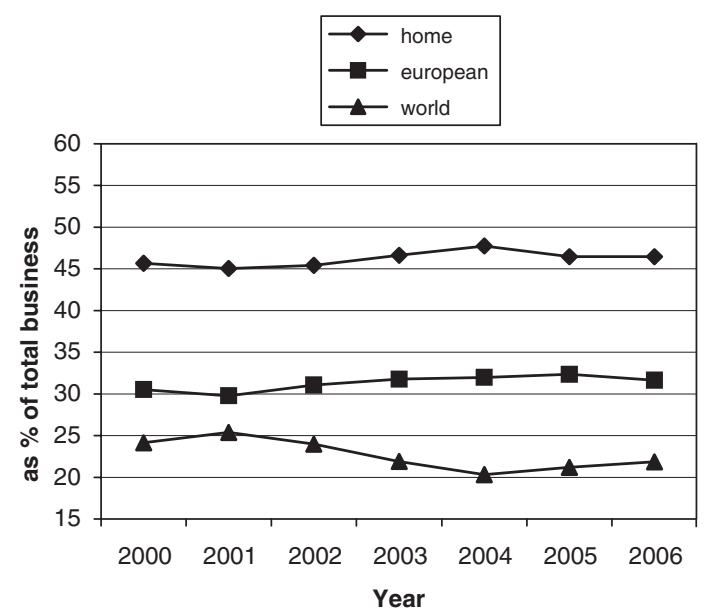

Figure 1. Development of the degree of internationalisation (weighted average).

the criteria. This finding suggests that our results are somewhat, although not excessively, sensitive to the choice of the criteria.

The insurance market: degree of internationalisation and trends

Figure 1 presents a weighted average of the cross-border activities of the 25 large EU insurance groups. Figure 1 shows that these EU insurance groups, which account for approximately 60 percent of total European premium volume, are very internationally oriented. In 2006 merely 46 percent of total group activities are conducted in the home country $(h=0.46)$, which means that 54 percent of the group activities are performed in host countries. The international activities are predominantly within Europe $(e=0.32)$ and less so in the rest of the world $(w=0.22)$. These figures differ from the cross-border activities of EU banks. Schoenmaker and Van Laecke ${ }^{16}$ find a stronger home bias $(h=0.53)$ for the 30 largest EU banks, a lower European component $(e=0.23)$ and a slightly higher global component $(w=0.25)$. It is clear that the insurance sector is more internationally oriented than the banking sector. These conclusions are in line with the results of Van der Zwet ${ }^{17}$ and Focarelli and Pozzolo. ${ }^{18}$

Figure 1 gives an overview of the development of the business over the different geographical areas. We find that the activities in the home country remain at the same level and that the activities conducted in the rest of Europe are slightly increasing from 31 percent in 2000 to 32 percent in 2006 . The percentage of business conducted in the rest of the world decreased from 24 percent in 2000 to 20 percent in 2004. This decrease can be explained by the economic downturn in 2000 , i.e. foreign activities were closed down to cut costs. After the recovery, the activities in the rest of the world

\footnotetext{
${ }^{16}$ Schoenmaker and Van Laecke (2006).

${ }^{17}$ Van der Zwet (2003).

${ }^{18}$ Focarelli and Pozzolo (2008).
} 
increased to 22 percent. To test whether there is a statistically significant trend (downwards or upwards) in the data, a statistical test proposed by Lehmann is applied. ${ }^{19}$ Looking at the trends, the increase in European activities is significant at the 5 percent level $(p=0.026)$.

\section{Organisational issues}

The international activities of insurance groups pose challenges to maintaining the oversight of the group activities (i.e. the risks the group is exposed to, risk diversification possibilities and the management of the group). This may fuel the demand for more coherent policies and a central steering mechanism within the organisation. However, insurance is very much a local business, as insurance is to a large extent influenced by country-specific factors, such as applicable rules and regulations, social security systems and fiscal treatment, which requires a more decentralised approach. In this section we examine the consequences of internationalisation on the organisational structure of insurance groups. In particular, we focus on the organisation of risk management and asset management functions, as these are the core elements of finance. We first reviewed the chapters on risk and asset management in the annual reports of our sample of insurance companies. Next, we conducted in-depth interviews with top managers of four large European (re-)insurance groups (i.e., Aegon, Fortis, ING and SwissRe) to gain further insight into the organisational structures.

\section{Integration of risk and capital management functions}

The organisational structure of international financial firms is moving from the traditional country model to a business line model with integration of key management functions. One of the most notable advances in risk management is the growing emphasis on developing a firm-wide assessment of risk. These integrated approaches to risk management aim to ensure a comprehensive and systematic approach to risk-related decisions throughout the financial firm. Although costly to realise, Flannery ${ }^{20}$ argues that once firms have a centralised risk management unit in place, they should expect to reap economies of scale in risk management. Nevertheless, these centralised systems still rely on local branches and subsidiaries for local market data. The potential capital reductions that can be achieved by applying the advanced approaches of the new Basel II framework encourage banking groups to organise their risk management more centrally. The same could also be true for the future Solvency II framework for the European insurance industry. Drzik ${ }^{21}$ argues that, as insurers consider how to implement new ways to measure and manage their business, they would do well to heed the lessons learned in the banking industry, which has been on a

\footnotetext{
${ }^{19}$ Lehmann (1975). This test statistic is $D=\sum_{i=1}^{n}\left(T_{i}-i\right)^{2}$, where $i$ indicates the year and $T_{i}$ is the rank of the score of year $i$.

${ }^{20}$ Flannery (1999).

${ }^{21}$ Drzik (2005).
} 
similar path for the last decade. Firms that implement a well-constructed risk and capital management framework can derive significant near-term business benefits, and substantially strengthen their medium-term competitive position. The emergence of CROs at the headquarters of large insurance groups confirms this trend towards centralisation.

Kuritzkes, Schuermann and Weiner ${ }^{22}$ provide evidence that internationally active financial conglomerates are putting in place centralised risk and capital management units. The dominant approach is to adopt a so-called "hub and spoke" organisational model. The spokes are responsible for risk management within business lines, while the hub provides centralised oversight of risk and capital at the group level. Activities at the spoke include the credit function within a bank, or the actuarial function within an insurance subsidiary or group, each of which serves the front-line managers for most trading decision-making.

These managers are familiar with the local conditions such as the business cycle (relevant for credit risk) and the legal and social security framework (relevant for actuarial risk) in a country. Moreover, aggregation across risk factors within a business line also typically takes place in the spokes, often in a finance unit that is responsible for funding and business reporting for the subsidiary. While the hub is dependent on risk reporting from the spokes, in many cases it is also responsible for overseeing the methodology development of an integrated economic capital framework that is then implemented within the spokes. The specific roles of the hub vary, but tend to include assuming responsibility for group-level risk reporting; participating in decisions about group capital structure, funding practices, and target debt rating; liaising with regulators and rating agencies; advising on major risk transfer transactions, such as collateralised loan obligations and securitisations; and in some institutions, actively managing the balance sheet. A case in point for insurance firms is group-wide asset and liability management done at the headquarters (hub).

\section{In-depth interviews}

This shift to a more holistic approach is confirmed by the interviews that were conducted. Most insurance managers indicate that they experience a clear trend towards centralisation of risk and capital management processes. Recent developments in the field of accounting (for instance the introduction of IFRS and the Sarbanes-Oxley Act in the U.S.A.) and in supervision (Solvency II) ensure that this trend will continue in the near future. Moreover, as insurance groups operate in various different countries, the need for a coherent policy regarding risk and capital management is increasing. This in turn has led to the adoption of CROs in large insurance groups.

\section{Hub functions}

The hub accommodates decisions and responsibilities for the group as whole at a central level in the organisation. Based on the annual reports and the interviews, we

\footnotetext{
${ }^{22}$ Kuritzkes et al. (2003).
} 
find that large insurance groups have a distinct central risk management framework in place. However, we also find great differences between the responsibilities and actual implementation of these frameworks. In some groups central risk and capital management processes are still in their infancy, while in other groups these processes are much more advanced and commonly accepted in the organisation.

All groups use their risk management framework to get an overview and to monitor the group-wide risk exposure. The majority of the groups also use their risk framework for specifying their risk appetite and setting risk management, control and business conduct standards for the group's worldwide operations (i.e. "the rules of the game"). This group-wide risk appetite specifies some risk tolerance levels. Within these risk boundaries the local units can act more or less independently. Furthermore, groupwide policies regarding risk management enable a broadly consistent approach to the management of risks at business unit level.

The risk management framework encompasses several bodies with their own specific tasks. On top of the central risk management framework is the group risk committee at executive level, with the CEO or CFO as the ultimate responsible. Often this committee is responsible for setting the strategic guidelines and policies for risk management, for monitoring consolidated risk reports at group level and for allocating economic capital ${ }^{23}$ to various entities of the group. Sometimes groups also have risk committees below executive level. This may be the case in a financial group with both banking and insurance activities. The group risk committee is then responsible for the group as a whole, while banking and insurance risk committees who report to the group risk committee are responsible for the risk management in the banking and insurance respectively.

Furthermore, many groups also have central or group risk management teams. These teams are responsible for the development and implementation of the risk management framework, for supporting the work of the risk committees, for reporting and reviewing risks and for recommendations in further developments in risk methodologies. Many times, these central/group risk management teams are headed by a CRO. This CRO oversees all aspects of a group's risk management, often reports to the CEO or CFO of the group and is present at meetings of the executive board.

All in all, one could argue that in a great number of insurance groups the hub is responsible for setting out "the rules of the game". How the spokes operate within these rules is examined below.

\section{Spoke functions}

In the spokes, decisions are being taken on the level of business/country unit. Insurance is very much a local business, with significant differences between the operational environment of the host countries in which the insurance group is active. A number of elements require specific local knowledge and therefore complicate the steering process at a central level. Specific local knowledge is required with respect to

\footnotetext{
${ }^{23}$ Economic capital is defined as the amount of capital an insurance company needs to absorb losses over a certain time interval (e.g. a year) with a certain confidence level (e.g. 99.9 percent).
} 
national rules and regulations, that is, legislation regarding fiscal matters, contracts, social security liability, consumer protection, or local risks.

These differences require that a great number of decisions still have to be made at the level of the local business units. In general, the actuary determines the specific risk models at local level. At the group level, these local models are subsequently monitored and assessed. Although the general conditions for determining these local risk models are set at the central level, the local units carry the ultimate responsibility for their risk management. Some groups even have local CROs.

So, despite the emergence of centralised risk management, the risk management practices of the largest insurance groups are still to a large extent influenced by the risk management policies of the local business units. Therefore, in general one could say that the "rules of the game" are being determined at central level in the hub and that the local managers in the spokes determine "how the game is actually being played" within the margins of these rules. This general principle is summarised in Figure 2. The figure gives an overview of the roles and responsibilities for each level of the organisation, whereby the spokes are placed within a field of jurisdiction-specific parameters in order to capture the location-specific factors that influence the business decisions.

\section{Asset management}

The picture with respect to asset management is somewhat similar to the developments in risk management. Based on the annual reports and the interviews, we observe a trend towards a more centralised approach to asset management. In a growing number of insurance groups, a holistic approach to asset management is pursued. Gaining economies of scale is an important driver for this trend, as - next to the "usual economies of scale" - pooling assets can lead to lower transaction costs (i.e. larger deals can be concluded at lower prices). However, this does not mean that all assets of the group enter into the same pool and are managed by a single asset management unit. Only one of the groups that we spoke to has a single asset pool, although others are planning to manage their assets through a single asset management unit. The emergence of large currency areas (i.e. the Euro area) and the integration of European financial markets are mentioned as the most important reasons for this trend.

\section{Hub functions}

Often Investment Committees, as well as Asset and Liability (ALM) Committees, at the group level set a group-wide policy on asset and liability management with minimum thresholds which the local business units are required to adopt. These committees in the hub ensure that the group-wide standards for asset management are applied at local level. In one insurance group, the group's overall asset/liability exposure is managed by the group's ALM and Investment Committee. The model parameters are managed and tested centrally in the hub and local variations take into account the differences in specific product types. Another group created a "chief" for the group's asset management operations. This person does not have "absolute power" in the asset management decisions but has a coordinating role within the 


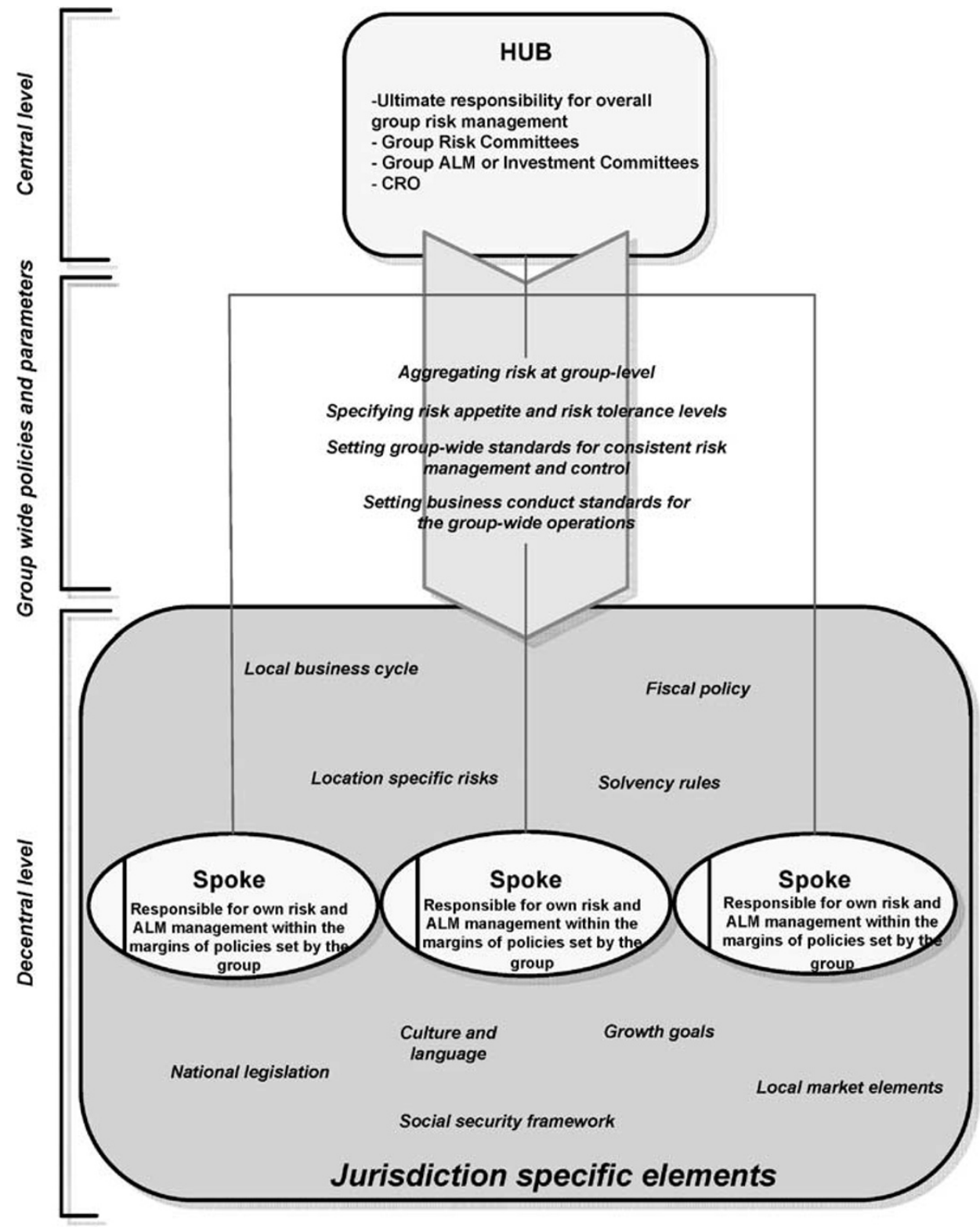

Figure 2. Organisation of risk and capital management in insurance groups.

organisation. The creation of this function has led to more consultation and coordination among the different asset management units in the group. However, the manager of this group indicated that for the time being, it is not possible to pool the assets of the whole group in one central asset management unit (although this is the 
ultimate goal). One insurance group indicated that they are implementing an advanced pooling system in one of their country units. This system enables bulk trading of assets through the pooling of the asset administration. In this system, the assets remain on the balance sheets of the country units while at the same time scale benefits in asset management are achieved.

Some groups have tried to centralise their asset management, but have had to cancel these attempts. An important reason for this is that these groups were confronted with additional costs, as they had to pay additional taxes on internal asset transactions. Another reason can be the lack of confidence between the different geographical units within an insurance group.

\section{Spoke functions}

Several groups manage their assets at the local level, while the general policies are determined at the hub. Again, one could say that "the rules of the game" are being determined at the central level in the hub, while the local managers can determine "how the game is actually being played" (see Figure 2). Local managers have to implement standards and guidelines for ALM that are determined in the hub, but have sufficient flexibility to adapt the general policies to local circumstances. In this way they are able to deal with the diversity of products and differences in regulation and legislation in the different jurisdictions.

With respect to the latter, one could think of restrictions regarding the allocation of written premiums. As a result, not all premiums can be freely invested across the world, a restriction that complicates the asset management from a central location. Therefore, insurance groups may be forced to keep a certain amount of their assets in the various countries in which they do business, irrespective of better investment possibilities elsewhere. However, one should note that most premiums and other assets are freely available and can be pooled and invested all over the world. It can therefore still be beneficial to manage the assets of the group from a central location.

\section{Conclusion}

The aim of this paper is twofold. First, we explore the current state of cross-border activities of the European insurance industry. Second, we examine how internationalisation affects the organisational structure of insurance groups.

Our data set of 25 large EU insurance groups illustrates that the insurance industry has a strong international orientation. Within a 7-year period (2000-2006) the number of insurance groups that can be regarded as "European" fluctuates around eight, when applying our criteria that 50 percent or more of their business is conducted abroad and that 25 percent or more of their business is conducted in other European countries. A further three to four insurance groups can be regarded as "global" players (50 percent or more of business is abroad and less than 25 percent in the rest of Europe). Furthermore, the weighted averages of the geographical segmentation of the insurance business show that about 55 percent of the business of insurance groups is conducted abroad. The European component increases from 31 to 32 percent from 2000 to 2006, while the global component decreases from 24 to 22 percent. These results are in line 
with conclusions of other studies, ${ }^{24}$ which also find that a substantial part of the activities of the large insurance groups is conducted outside the home country.

We subsequently examine how internationalisation affects the organisational structure of insurance groups. In particular, we focus on the organisation of the risk and capital management functions, as these are the core elements of finance. Based on in-depth interviews with high-level managers of a number of large European insurance groups, we find a clear trend towards centralising risk and capital management activities within large insurance groups. First, the size of the organisation as well as the significant international presence result in a growing demand for a centralised view of the group's capital and the risks the group is exposed to. Second, the move to international accounting standards (IFRS) and advanced risk models for capital (Solvency II) give a boost to centralisation. Third, by making optimal use of the available knowledge in the organisation, a group-wide framework can be established, which is often reflected by setting central parameters in which the local business units have to act. Many insurance groups have group-wide frameworks (or indicate that they are working on those) for risk and capital management.

Although variation exists in the state of play of the centralisation process, the function in the hub (centre) is more or less based on the following elements: aggregating risk at group level, specifying risk group appetite and risk tolerance levels, setting group-wide standards for consistent risk management and control, and setting business conduct standards for the group-wide operations. However, since insurance has a strong local focus (as every jurisdiction has its own specific characteristics with respect to legislation, culture, fiscal policy, social security, etc.) the insurance groups still have to give a lot of responsibilities to managers of the local business units. After all, they are familiar with these country-specific elements and have the knowledge that is needed to manage the firm adequately and to take the appropriate decisions. It is thus almost impossible to steer and manage all the processes at the central level in the organisation. The centre rather functions as a coordinator and it sees to it that practices of local managers do not diverge too much.

It can therefore be concluded that the international presence in various jurisdictions has given rise to a shift to a more holistic approach towards risk and capital management, although local knowledge is still needed to properly operate within the national markets. The dominant pattern is that the "rules of the game" are determined at the central level (the hub), while the actual implementation of these policies is more or less left up to the local managers (the spokes). This enables a coherent policy for managing risk and capital, while local management is given sufficient room to take account of local practices and developments.

A question for future research is to what extent geographic expansion of insurance groups leads to diversification benefits and consequently to a higher valuation of international insurance groups. While the answer to the first question is very likely to be positive, the answer to the second question is not clear.

\footnotetext{
${ }^{24}$ E.g. Van der Zwet (2003).
} 


\section{References}

Berger, A. and DeYoung, R. (2006) 'Technological progress and the geographic expansion of the banking industry', Journal of Money, Credit and Banking 38: 1483-1513.

Berger, A., Dai, Q., Ongena, S. and Smith, D. (2003) 'To what extent will the banking industry be globalized? A study of bank nationality and reach in 20 European Nations', Journal of Banking \& Finance 27: $383-415$.

Comité Européen des Assurances (2005) European Insurance in Figures. The European Insurance Industry, Brussels: Comité Européen des Assurances.

Drzik, J. (2005) 'At the crossroads of change: Risk and capital management in the insurance industry', The Geneva Papers on Risk and Insurance - Issues and Practise 30: 72-87.

Flannery, M. (1999) 'Modernising financial regulation: The relation between interbank transactions and supervisory reforms', Journal of Financial Services Research 16: 101-116.

Focarelli, D. and Pozzolo, A.F. (2008) 'Cross-border M\&As in the financial sector: Is banking different from insurance?', Journal of Banking \& Finance 32: 15-29.

Kuritzkes, A., Schuermann, T. and Weiner, S. (2003) 'Risk measurement, risk management, and capital adequacy in financial conglomerates', in R. Herring and R. Litan (eds) Brookings-Wharton Papers on Financial Services: 2003, Washington, DC: Brookings Institution.

Lehmann, E. (1975) Nonparametrics: Statistical Methods Based on Ranks, San Francisco: Holden Publisher Inc.

Moshirian, F. (2006) 'Aspects of international financial services', Journal of Banking \& Finance 30: 10571064.

Organisation for Economic Co-operation and Development (OECD) (2005) Statistical Yearbook, Paris: OECD Publishing.

Schoenmaker, D. and van Laecke, C. (2006) Current state of cross-border banking, FMG Special Paper, no. 168, London School of Economics, London.

Schoenmaker, D. and Oosterloo, S. (2005) 'Financial supervision in an integrating Europe: Measuring crossborder externalities', International Finance 8: 1-27.

Slager, A.H.M. (2004) Banking Across Borders, Rotterdam: Erasmus Research Institute of Management.

Sullivan, D. (1994) 'Measuring the degree of internationalization of a firm', Journal of International Business Studies 25: 325-342.

Van der Zwet, A.M.C. (2003) 'The blurring of distinctions between financial sectors: Fact or fiction?', $D N B$ Occasional Studies 1(2): 1-26.

\section{About the Authors}

Dirk Schoenmaker has been Director European Affairs, Competition \& Consumer Policy at the Ministry of Economic Affairs in the Netherlands since 2008. For the previous 10 years, he served at the Financial Markets Policy Directorate of the Ministry of Finance. Since 2004 he has also been a part-time professor of Finance, Banking and Insurance at the VU University Amsterdam. He earned his Ph.D. in economics at the London School of Economics.

Sander Oosterloo is a senior policy advisor at the Netherlands Ministry of Finance. Since 2002 he has been working on issues ranging from banking regulation and financial crisis management to the conduct of business issues and retail financial services. He obtained his Ph.D. at the University of Groningen, and has written on institutional frameworks for financial stability, accountability of supervisory authorities, financial integration and challenges in EU supervision.

Otto Winkels has been working at the Operational Risk Management department at AEGON, in the Netherlands since 2006. He studied economics at Tilburg University. 